\title{
Teachers' Practices in Language Online Courses in Higher Education during the COVID-19 Health Emergency
}

\author{
Prácticas de enseñanza en línea en los cursos \\ de idiomas en la educación superior durante \\ la emergencia sanitaria COVID-19
}

EVELYN ALMEIDA ( $\left.{ }^{a} a, b\right)$, DIEGO CAJAS (c), ANDRÉS BALDASSARI (a), SANTIAGO SANGUÑA (a)

(a) Universidad Central del Ecuador, Av. Universitaria, Quito - Ecuador

(b) Universidad de las Fuerzas Armadas ESPE, Av. General Rumiñahui s/n y Ambato, Sangolquí - Ecuador

(c) Universidad Nacional de Educación UNAE, Av. Independencia s/n, Sector Chuquipata, Azogues - Ecuador

*evalmeida@uce.edu.ec

\begin{abstract}
I In 2020, the entire world experienced a pandemic caused by the COVID-19 virus. This pandemic drew most of the entire world population to confinement, causing dramatic changes in most people's everyday activities, for instance, education. Most countries modified their educational systems and moved from a face to face education to an online mode. By using a survey design, this study aims to describe the online teaching practices of 51 language teachers working at the language center of a university. Results show that language instructors working in this
\end{abstract}

institution did not receive clear instructions on how to move from face to face to an online mode effectively. Additionally, results show that they have limited understanding of online education, a lack of a proper online education training among language teachers, and limited knowledge of how to properly integrate technological tools into an online mode.

Keywords: Teachers' practices, online courses, teaching languages, COVID-19 


\section{RESUMEN}

En el 2020, el mundo entero experimentó una pandemia causada por el virus COVID-19. Esta pandemia ocasionó a la mayoría de la población mundial al confinamiento, causando cambios dramáticos en la mayoría de las actividades cotidianas de la gente, por ejemplo, la educación. La mayoría de los países modificaron todos sus sistemas educativos y pasaron de una educación cara a cara a una modalidad en línea. Empleando un diseño de encuesta, este estudio tiene como objetivo describir las prácticas de enseñanza en línea de 51 profesores de idiomas que trabajan en el centro de idiomas de una universidad. Los resultados muestran que los profesores de idiomas que trabajan en esta institución no recibieron instrucciones claras sobre cómo pasar de una modalidad presencial a una en línea de manera efectiva. Además, los resultados muestran que los maestros tienen una comprensión limitada de la educación en línea, y que existe una falta de capacitación adecuada en educación en línea entre los maestros de idiomas y un conocimiento limitado sobre cómo integrar adecuadamente las herramientas tecnológicas.

Palabras Clave: Prácticas de profesores, clases en línea, enseñanza de idiomas, COVID-19

\section{INTRODUCTION}

As a response to COVID-19 global Pandemic 2020, which drew people into confinement, educational authorities worldwide changed their teaching modality from a face to face instruction to an online or remote mode. Unfortunately, the majority, if not all, educational institutions were not prepared to assume these unexpected changes.
Along with the global efforts done in health, business, and services to continue functioning within the pandemic, educational institutions endeavor to continue their instruction started offering online education in all primary and secondary sectors and higher education. However, this was not an easy task since institutions faced problems regarding teachers' preparation to conduct online classes, students' access to internet or electronic devices for online classes, motivation, curriculum modifications, and limited policies that would facilitate effective implementation of the curriculum.

As the result of the pandemic, all universities started offering their instruction in an online mode in Ecuador. For some institutions, this was not complicated since they offered online education programs for some years. This experience allowed them to have a proper technological infrastructure that facilitated the design of their virtual classrooms and their class organization. Opposite to this, other institutions greatly struggled to adopt an online mode of instruction due to the lack of experience in this area, technological infrastructure, and above all, the limited time they had to modify their instruction method.

Despite the marked differences existing between these two types of universities, what was shared is that university administrators had to open the semesters without any delay and had to deal with instructors who, in most cases, had limited or no experience in online education. These students were not interested in this learning method and, in some cases, students did not have any internet access. Hence, putting instruction on standby for a 
semester was not an option and the burden of making the online instruction effective laid entirely on the teachers' shoulders. However, some institutions trained their faculty and tried to organize the online learning process via policies and regulations. It is essential to highlight that most universities' lack of preparation was the product of the pandemic and the limited time they had to introduce this change.

The challenges faced by undergraduate and graduate programs were also experienced by language centers belonging to Ecuadorian universities. Language instructors working in these centers also felt the pressure to provide quality language learning education. The problem that this study aims to address is the lack of teachers' training in online education and the lack of educational policies that pave the way for online learning. The purpose of this study is also to describe not only teachers' online teaching practices and institutional educational policies during the quarantine period, but also to present different approaches, methods, assessment, and suggestions for online language education. Using a survey design, researchers collected information from 51 language instructors from a language center in a university in Quito-Ecuador.

\section{LITERATURE REVIEW}

The entire education system in Ecuador has moved to an online mode due to government measures to control and reduce the spread of the COVID-19 virus. This change, however, has caused distress to some teachers and students due to the lack of preparation to teach or study in this mode of instruction.
To cope with the new contextual teaching demands and to maintain quality in education, university administrators had to change the mode of instruction and adapt the existing technological infrastructure to online teaching. In line with this organization, administrators had to pave the way for proper online education where instructor needed to have an essential role. Unfortunately, some teachers were not included in this process and found themselves facing online classes without proper academic direction, or clear-cut implementing guidelines to facilitate their new online teaching practice. When describing teachers' practices in online courses, there are some aspects to consider, for instance, the main differences between face-to-face and online learning, the importance of teacher training (Wozney, Venkatesh \& Abrami, 2006), administration and policy support (Reimers \& Schleicher, 2020), and teachers' attitudes (Ananga \& Biney, 2018).

\section{Face to face vs. Online Education}

The expansion of services in higher education is increasing due to a growing demand for access to universities. This demand has influenced institutions to widen their academic offer and consider different modes of instruction to cope with this situation. Ananga and Biney (2018) mention that adult learners are looking for new alternatives to effectively and flexibly develop their studies.

Unfortunately, most adult learners who aim to combine their personal lives with their education have encounter barriers to advance academically in a traditional system of instruction. Generally, face to face instruction is a fixed model where students and teachers' physical presence is a must since they 
need to share the same physical environment (lbañez, 1998). In this model, learners are not entirely autonomous during their learning process. Students work under the academic guidance of their professors in the same place and at the same time. This system suits students whose primary responsibility is to study and not to have additional obligations and to exclude people from other responsibilities, such as supporting or working for their families. Moreover, through online education, students develop knowledge and skills (Forte \& Blouin, 2016) without putting aside their current responsibilities, such as work or family.

Opposite to the rigid face to face mode of education, online education has been favorably positioning itself as an alternative mode that caters to a broad group of people who otherwise would not have had access to education. In the last 25 years, models such as CMC (Computer-Mediated Communication) have brought significant findings to online instruction in terms of theory and practice and have highlighted the effectiveness of online and blended learning (Chen \& Wang, 2008; Toyama, Murphy and Baki, 2013). With these findings, educational institutions have developed more effective curricula and a more flexible academic and administrative organization.

Online education cannot be seen as an individual process in which students learn isolatedly without interaction or input from their virtual classmates. Gone are the days when students who opted for this education mode interacted only with their teachers and online course instructional materials. Hrastinski (2009) encourages educators to plan online courses that move from an individualistic student's instruction to more inclusive teaching, promoting active students' participation and collaboration with their peers. To do this, he provides four suggestions, namely: the creation of learning communities, the inclusion of social media platforms as part of the course instructional materials and construction of online activities that promote high-order thinking skills, and peer-collaboration. These suggestions can frame the new methodological direction of online education.

In the same vein, Pichicciano (2017) encourages teachers to create "learning environments or communities," which pave the way for students to exchange "ideas, information, and opinions" to construct knowledge. Thus, teachers have to deal effectively using suitable online tools and teacher-made materials according to their students' context, interests, and access to technological devices. When developing online courses, instructors need to avoid designing students' individual instructional activities targeting solely academic content. Instead, this content needs to be co-created and produced by students despite their physical interaction. Instructional materials play a fundamental role in scaffolding students' cooperation and construction of knowledge. Within this emerging conceptualization of online education, Transue (2013) states that online teachers should journey together with their students during their academic formation and help them identify and acknowledge the importance of the learning materials which comprise their online courses. Online education, therefore, needs to be propelled by the teacher's innovation and creativity.

\section{Teacher training}

Despite the technological advances in online education, the teachers' role is of primal importance as it is in face to face 
education. Online instructors are generally in charge of designing their courses, organizing the academic content sequence, and facilitating student learning; hence the importance of constant training. Teacher training is instrumental in developing teacher's competency with technological applications, which are, in turn, fundamental to create practical online courses. Technical training, however, needs to be complemented with teaching methodology. Both types of training complement each other and should be seen as equally important.

Proper training also influences teachers' attitudes towards computers (Wozney, Venkatesh \& Abrami, 2006), resulting in a positive perception of their use (Ananga \& Biney, 2018). Welltrained teachers are capable of delivering effective online classes, which increase learner's motivation, interaction, and satisfaction.

As previously mentioned, online education should be characterized by innovation and creativity; thus, proposing a single and prescriptive teacher training model for online teaching seems complicated. Teacher training for online education needs to target three domains, namely, integration of technological tools in the learning process, creation of participatory and cooperative virtual environments, and construction and development of online instructional materials. Unfortunately, teacher training in online education, in Ecuador particularly, has been mostly reduced to the mere use of technological tools.

The training that teachers receive shaped their attitudes. Hence the importance of offering valuable training to instructors. Thus, schools' administrators must organize training, on remote teaching-learning and promote networks between teachers and professional communities.

\section{Administration and policy support}

Because of the pandemic caused by the COVID-19 virus, most educational systems in the world have been dealing with an online teaching and learning crisis. In most cases, a lack of technological infrastructure and the legal and regulatory structure were faced to respond to the demands of quality online instruction. The latter is of particular importance since the absence of a systematic policy and planning can hinder teachers' efforts to incorporate technology in their classes (Cuban, 2000; Morton, 1996; Wozney, Venkatesh \& Abrami, 2006), which endangers the achievement of students' learning goals.

Reimers and Schleicher (2020) establish that educational institutions need clear policies and feasible proposals to implement academic protocols in response to the COVID-19 pandemic of 2020. Policies include educational features based on a proactive approach to prevent learning delays.

A proper educational administration and effective policies to adapt to online teaching methodologies in schools are essential. Authorities need to motivate stakeholders and, at the same time, manifest a proper leadership within the institutions. Authorities' responses to unplanned events are imperative because their attitudes can affect their school performance (Marcinkiewicz, 1996). To facilitate proper institutional administration, institutions need to create innovative policies that help control and assess the whole educational and administrative processes. Policymakers cannot design their policies isolatedly. They need direction from the research community on how schools can develop their curricular plans and regulations that are relevant and sensitive to technology integration (Morton, 1996). 
One of the biggest lessons related to educational policies that this health emergency has taught us is adaptability and flexibility, and the need to provide direction to all stakeholders. Still, they do not have to be constrictive, and they must be continuously revised to respond to the new emerging changes in society.

An example of policy adaptability in response to COVID-19 is the one provided by Reimers and Schleicher (2020). They suggest changes in "curriculum, content delivery, professional development, and promotion of communication and collaboration among institutions" (p. 5). Regarding curriculum, they highlight the value of revising the curriculum goals and the creation of bridging programs to facilitate learning. For content delivery, they advocate for a variation of it that considers alternative means beyond internet; they also encourage institutions to seek collaboration with the private sector to help students who do not have access to online resources. Professional development is the cornerstone for any innovation, thus the need to include it in any educational change. Finally, the promotion of communication and collaboration among institutions via learning communities is required.

\section{METHODOLOGY}

This research is a quantitative study that aims to describe the current situation of teaching foreign and ancestral languages in the language center of a university in Quito through a survey design. The population for this study comprised 42 English teachers (82\%), five Italian teachers (10\%), three French teachers (6\%), and one Kichwa teacher (2\%) who responded to a 21 -question online questionnaire.
To construct the questionnaire, the researchers based the questions on the stages of planning a questionnaire from Roopa and Rani (2012) including initial considerations, questions content and structure, pilot and revision, and final questionnaire. The questions included close-ended and open-ended questions, and they were also validated by an expert.

Using SPSS software, descriptive statistics was used for analyzing the data. The questionnaire aimed to capture the perceptions of participants towards online education and online teacher training. Note that majority of the participants had limited or null online teaching experience. Currently, they all are teaching online language courses as a consequence of the pandemic.

\section{ANALYSIS OF THE RESULTS}

During this pandemic, many educational institutions changed the way that they have typically been teaching. These changes significantly differ from one institution to another and, in some cases, between academic departments within the same institution. This is the case of some language centers in different Ecuadorian universities. For instance, in the language center where this research took place, $98 \%$ of respondents stated that due to the shift to virtual education, they had to change their teaching methodology to adapt to the new instructional demands. In contrast, the remaining $2 \%$ stated that they did not change. It can be inferred that the latter did not change their methodology because they did not have enough knowledge or ability to deliver online language classes. This percentage coincides with $2 \%$ of respondents who believed that internet is not necessary for online teaching, as presented later in Table 2. However, it is essential to do more research to establish if there is a correlation among instructors' knowledge of online language education and how they exercise their agency when teaching foreign languages. 


\section{Teachers' perception of online teacher training}

Students' performance in online education goes hand in hand with teachers' technological competency (Ananga \& Biney, 2018). Also, the teacher's technological knowledge is a great advantage when a student has a problem since the teacher can plan diverse technological options to help their students perform effectively in their online courses.

Regarding teachers' training on online teaching, 25,5\% of the instructors mentioned that they did not have any training, and $74.5 \%$ said they had training in online teaching methodology. It is important to note that most respondents $(90,2 \%)$ mentioned having online training added that they had acquired online teaching knowledge on their own via informal education. In other words, their knowledge of online teaching may be empirical; thus, it may lack the theoretical foundations of education.

The problem with separating the use of technological tools from the core educational theories is that it may reduce online teaching to a mere mechanical act of instructors using unconnected online tools without a specific purpose.

Regarding the place where respondents received their online teaching education, there is a low number of instructors who acquired such training during their pre-service formation (11 out of 51 instructors) whereas the majority were trained in their workplaces (39 out of 51 instructors), and 46 obtained their training via self-instruction. This situation shows the need for universities to do an extensive pre-service curriculum analysis and, with such, subsequent modifications to form teachers who can respond to different educational settings (Figure 1).
Figure 1

Respondents' Online Training

Training in Online Teaching

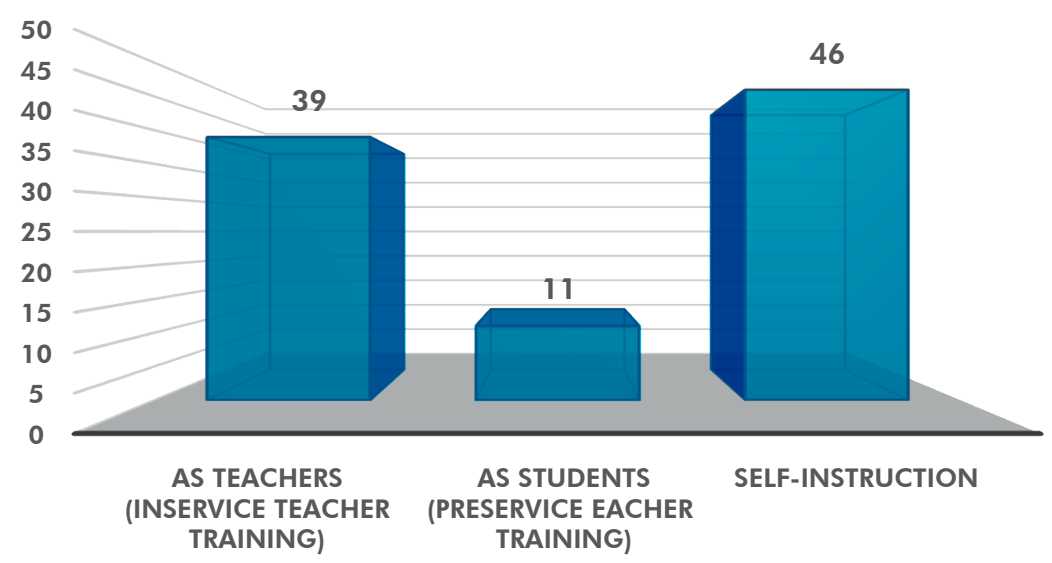

Note. This situation shows the need for universities to do an extensive preservice curriculum analysis and, with such, subsequent modifications to form teachers who can respond to different educational settings.

Another aspect that is important to consider is the length of experience in online teaching that respondents had. Though most respondents mentioned that they had had some training in online teaching, they do not have many years of experience working in this mode. In fact, $78.4 \%$ of the respondents had one year or less than a year of experience teaching online courses, $17.6 \%$ had from 1 to 3 years of experience, and only $3.9 \%$ had more than three years of teaching online experience. Furthermore, these results corroborate the assumption that most teachers who are currently teaching online see this type of education as a simple use of technological tools and applications to deliver academic content. This lack of experience may have also influenced respondents' online teaching practices and how they organize their courses as presented below. 


\section{Online teacher's methodology}

On averge, each online class has from 20 to 25 students (Table 1). According to the respondents, this number of students allows them to develop different activities such as video presentations, share audios, or work on shared online documents such as google docs.

\section{Table 1}

Number of Students Per Class

\begin{tabular}{|c|c|}
\hline $\begin{array}{c}\text { Number of students } \\
\text { per class }\end{array}$ & $\begin{array}{c}\text { Percentage } \\
\text { (\%) }\end{array}$ \\
\hline 10 to 15 students & 3.9 \\
\hline 15 to 20 students & 13.7 \\
\hline 20 to 25 students & 45.1 \\
\hline More than 25 students & 37.3 \\
\hline
\end{tabular}

Note. According to the respondents, this number of students allows them to develop different activities such as video presentations, share audios, or work on shared online documents such as google docs.

Regarding language content delivery, respondents showed a high preference for synchronous instruction $(88,2 \%)$ using different online tools such as Zoom, Google Meet, or Teams from Microsoft. Only 2\% of teachers used asynchronous learning, including pre-recorded classes, and $26 \%$ of them used both.
Most respondents also added that they complemented their synchronous instruction with educational platforms (84.3\%). The high percent of synchronous classes, which means that all students need to be connected online at the same time, threatens another core principle of online education, which is flexibility.

Based on the data, it seems that most instructors maintain the same structure of their face to face instruction with the only difference that now it is delivered in a virtual environment. This situation manifests the importance of the creation of institutional policies that help them navigate in different teaching circumstances and contexts.

Though teaching in the current health situation caused by the pandemic is challenging and problematic for everybody, stakeholders should not turn their backs to the learning opportunities resulting from the present scenario. For instance, special attention needs to be placed on educational policies that are established by educational institutions, teacher's capability to respond to unexpected and sudden changes, curriculum flexibility, and the extent of educational innovation existing in the country.

In relation to instructors technological tools in their online classes, respondents showed a high preference for video conferencing, learning platforms, and videos made by other people (YouTube). In a lower percentage, they also used collaborative documents such as google docs, and in a reduced portion, teachers made their own videos to help students in their language learning. (Figure 2). 
Figure 2

Use of Technological Tools

\section{Technological Tools}

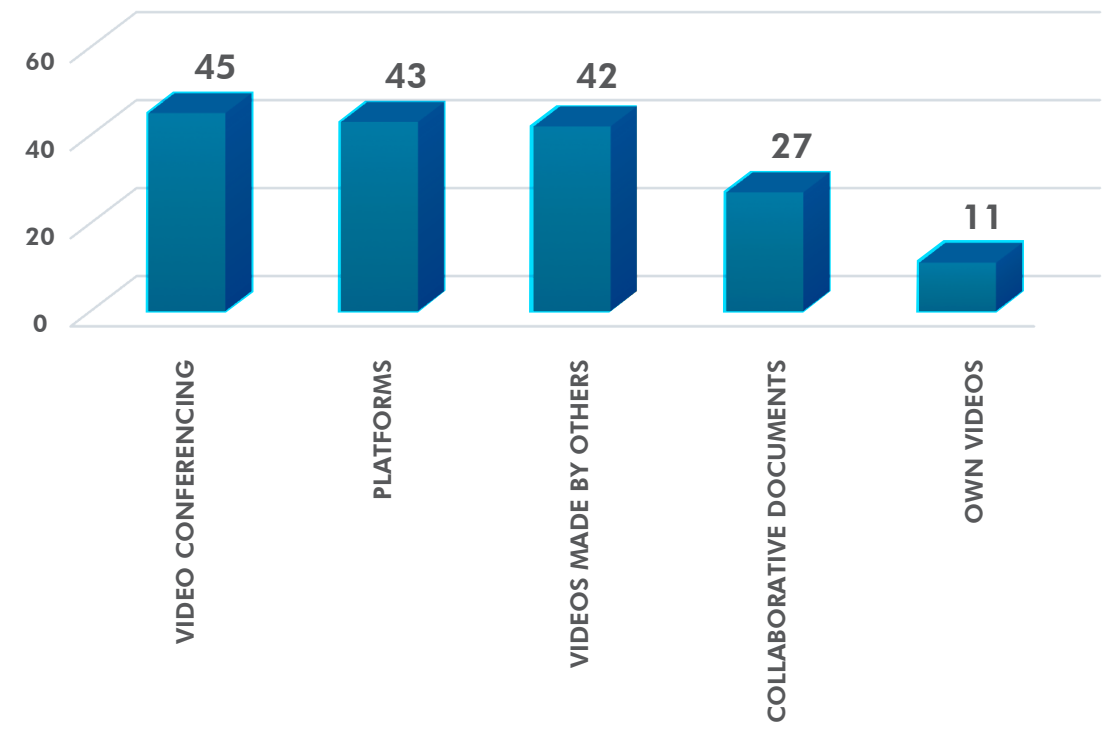

Note. In a lower percentage, they also used collaborative documents such as google docs, and in a reduced portion, teachers made their own videos to help students in their language learning.

The preference for using others' resources shows that instructors are not creating their own instructional materials. However, and despite this, they mentioned that in general, they spent more time for planning and assessing students' works than in the previous face to face mode; for instance, 54\% spent from 2 to 4 hours a day per online class, $35.3 \%$ from 4 to 6 hours. This situation brings about instructors priorities and makes a person wonder: should teachers prioritize instruction or assessment? Or what would the mechanisms be to promote a proper combination of teaching and assessment?

\section{Teachers' perceptions of online education}

Regarding instructors perception of their teaching, assessment, and their students, $56.8 \%$ of teachers believed that students are ready to receive online classes. In comparison, $84.43 \%$ of respondents thought that they are prepared to teach online. This difference in the readiness to receive classes and teaching manifests a contradiction between the teacher's role and the core of online education. As it was mentioned before, the strengths of online education are flexibility and accessibility. Believing that students need to have specific preparation before starting their online learning contradicts these two principles. Hence, appropriate and scientific online teacher training is crucial to popularizing the advantages and strengths of online education.

Furthermore, $74.5 \%$ of teachers considered that their professional practice had been affected by the health emergency and the subsequent change to online education. $80.4 \%$ believed that the learning process of students has also been affected. However, $92.2 \%$ of instructors thought that the online mode was the best option for this period under the current circumstances.

These findings suggest that instructors in general, do not have a proper understanding of online teaching. Studies indicate that appropriate online education can be equalized to face to face education if adequately planned and implemented. By believing that the students' learning will be affected, teachers are implying that online education cannot have the same quality as face to face. 


\section{Resources for language teaching and learning}

Resources for virtual language teaching and learning refer to the devices and support materials students and instructors need. Devices are, for instance, computers and cellphones. E-books, printed textbooks, printed resources (worksheets, flashcards), and printers correspond to support materials that facilitate learning, and internet refers to the means to deliver language virtual education. Table 2 shows the respondents' perceived importance of these resources for instructors and students.

Table 2

Resources for Language Teaching and Learning

\section{Types of Resources $\quad$ Teachers $\quad$ Students}

$98 \%$

$41,2 \%$

$31,4 \%$

instructors and students.
Table 2 shows some variation between what teachers perceive is essential to teach languages online versus what they believe students need. For instance, $2 \%$ of them mentioned that they do not need internet to teach languages online. This percentage contradicts one of the main characteristics of online education. Due to the advances in technology, internet has become the backbone of virtual education. Without internet, it is virtually impossible to deliver or receive online language classes.

Regarding devices, computers are perceived to be more necessary than cellphones for instructors than for students. It may be due to the existing association of the use of tools with users' age. Teachers' preference for computers over cellphones may be associated with the facilities these devices have; computers are bigger than phones, and instructors, despite their age, are more familiar with them. Young generations, on the other hand, have extended the use of cellphones beyond calls and texts. Through applications, they create and edit videos, access virtual classrooms, learn foreign languages, create class presentations, etc.

Further, cellphones are cheaper than computers, thus, more accessible for students. This situation, combined with students' preference that have for cellphones, poses a new venue for instructors to explore. When planning language classes, language instructors need to consider that their activities work effectively with computers as well as with cellphones.

Regarding support materials needed for online language teaching and learning, it is crucial to notice that respondents 
are still associating online education with the use of printed textbooks, e-books, printed resources (worksheets, flashcards), and printers. Table 2 shows that $51 \%$ of respondents need printed textbooks, $88,2 \%$ need e-textbooks to teach online, and a representative percentage of respondents $(41,2 \%)$ believe that students also need to use books and printed resources. Using printed or e-textbooks in online language education seems not to be the best option since it limits the use of various free online tools existing on internet.

Furthermore, believing that a single textbook (printed or digital) and printed materials are needed for teaching and learning languages via online contradicts online education principles, such as accessibility and the use of a wide range of interactive tools. This arrangement also curtails tutors and students' creativity and agency since the entire course activities revolve around the use of such limited resources. It also promotes students' exclusion since some of them do not have money to pay for textbooks neither to buy printers.

This study particularly shows that teachers need to have more training first on the pedagogical aspect of online language teaching, and second, training on the use of technology, online methodologies and techniques. When instructors design their courses, they need to prioritize their learners' knowledge and focus on their learning styles and promotion of language interactions.

On the other hand, administrators need to be more flexible and respond to the emerging educational demands within an appropriate timeframe. Instructors need direction and guidance before and during the implementation of any pedagogical and methodological change. However, this guidance does not need to be based on prescriptions, but on general principles. Ellis (2005) highlights the necessity of principles in language teaching, mainly because it allows teachers to be creative and innovative since principles are general practices and do not constraint the implementation of innovations. At a classroom level, online courses need to consider the learner's built-in syllabus, extensive language input, opportunities for output, interact in the target language, which is central to developing second language proficiency, need to take account of individual differences. (As cited in Chen \& Wang, 2008).

\section{CONCLUSIONS}

The sudden changes in the teaching modality that all universities experienced due to the pandemic resulted in a general acceptance of online education. Notably, in language teaching and learning, this change has brought forth its advantages and has minimized its disadvantages. The benefits are time flexibility, access to foreign or ancestral language courses despite students' residency and learning pace. In this diverse instruction, most teachers use different teaching methodologies and promote students' autonomous and cooperative learning.

On the contrary to the advantages, through online language education, students' inequalities have emerged dramatically. For example, due to their socioeconomic status, some students 
have limited internet access or, in some cases, no access at all. This situation has impeded the proper progress and development of their language skills. Also, students do not have devices to connect to classes and subsequently work on their assignments. They are also unable to purchase textbooks due to their price. From a macro perspective, it is the government's responsibility and the institutions to create projects that aim to facilitate access to the internet and provide students with the necessary devices to virtually access and work on their online language classes. From a micro perspective, language centers administrators, and instructors need to diversify instructional materials and move from a single use of expensive textbooks to a more diverse use of free online resources. In planning their classes, instructors need to consider that not all students have computers and access to their language classes through their cellphones. Thus, it is the teachers' responsibility to consider this aspect when developing their language classes.

Teacher's training plays a fundamental role in facilitating innovation, particularly in online education, though, it needs to focus first on the understanding of pedagogical principles that support this type of education. Once these principles are understood, the teacher's training can move into the use of technological tools. Such practice focuses only on the use of specialized tools and it may result in instructors using a series of unconnected activities that may not help students achieve the learning outcomes. Teacher's training needs to be complemented by appropriate and contextualized educational policies since it paves the way for educational innovation and change.

\section{REFERENCES}

Ananga, P., \& Biney, I. K. (2018). Comparing face-to-face and online teaching and learning in higher education. MIER Journal of Educational Studies, Trends and Practices, 7(2).

Chen, N.-S., \& Wang, Y. (2008). Testing Principles of Language Learning in a Cyber Face-to-Face Environment. Educational Technology \& Society, 11 (3), 97-113.

Cuban, L., Kirkpatrick, H., \& Peck, C. (2001). High access and low use of technologies in high school classrooms: Explaining an apparent paradox. American educational research journal, 38(4), 813-834.

Forte, K. S., \& Blouin, D. (2016). Fostering transformative learning in an online ESL professional development program for K-12 teachers. The Qualitative Report, 21 (4), 781.

Hrastinski, S. (2009). A theory of online learning as online participation. Computers \& Education, 52(1), 78-82.

Ibáñez, R. M. (1998). La educación del sigloXXI. Hacia un sistema tecnológico multimedia. Las universidades a distancia. Educación XX1, 1(1).

Marcinkiewicz, H. R., \& Regstad, N. G. (1996). Using subjective norms to predict teachers' computer use. Journal of Computing in Teacher Education, 13(1), 27-33.

Morton, A. (1996). Factors Affecting the Integration of Computers in Western Sydney Secondary Schools.

Picciano, A. G. (2017). Theories and frameworks for online education: Seeking an integrated model. Online Learning, 21 (3), 166-190.

Reimers, F. M., \& Schleicher, A. (2020). A framework to guide an education response to the COVID-19 Pandemic of 2020. 
Roopa, S., \& Rani, M. S. (2012). Questionnaire designing for a survey. Journal of Indian Orthodontic Society, 46(4_suppl1), 273-277.

Transue, B. M. (2013). Connectivism and information literacy: Moving from learning theory to pedagogical practice. Public services quarterly, 9(3), 185-195.
Wozney, L., Venkatesh, V., \& Abrami, P. (2006). Implementing computer technologies: Teachers' perceptions and practices. Journal of Technology and teacher education, 14(1), 173-207.

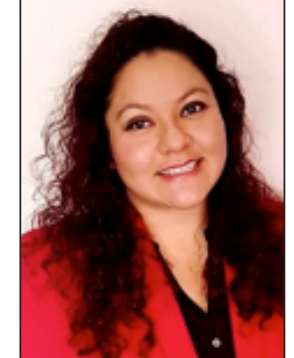

\section{EVELYN ALMEIDA}

- Docente investigadora, enseña inglés y materias relacionas a la investigación y evaluación en dos prestigiosas universidades de Quito, la Universidad Central del Ecuador y la Universidad de la Fuerzas Armadas ESPE, de las cuales es ex alumna. Actualmente es directora del Instituto de King Sejong Quito en la Universidad Central del Ecuador.

- Evelyn es candidata a Ph.D. en el Programa de Lenguas, Alfabetización y Estudios Socioculturales en la Facultad de Educación de la Universidad de Nuevo México en Estados Unidos. Su concentración en la enseñanza de angloparlantes de otros idiomas (TESOL), un campo en el que tiene una gran formación académica, experiencia profesional e interés personal.

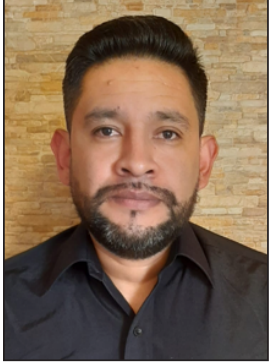

\section{ANDRES BALDASSAR}

- Profesional con 20 años de experiencia en docencia media y superior. Además, se ha desempeñado como capacitador para docentes a nivel medio en el uso de estrategias para desarrollo de competencias lingüísticas en lengua extranjera. Sus estudios en el idioma los realizó en la Comisión Fulbright y CEC de la Politécnica Nacional. Sus estudios de licenciatura los llevó a cabo en la Universidad Central del Ecuador. Adicional cuenta con una Maestría en Lingüística Aplicada a la Enseñanza Bilingüe por parte de la Pontificia Universidad Cató lica del Ecuador. Su especialidad la ha complementado con estudios en Neurolingüística y Coaching Ontológico. Actualmente se desempeña como docente del Instituto Académico de Idiomas de la Universidad Central del Ecuador.

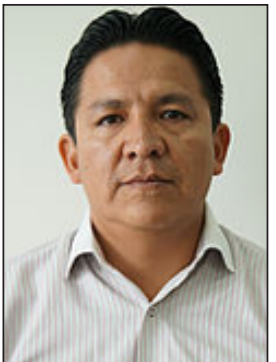

DIEGO CAJAS

- Diego Cajas es PhD en Applied Linguisics por la Universidad de Warwick del Reino Unido. Actualmente es el director de la Carrera de Pedagogía de los Idiomas Nacionales y Extranjeros en la Universidad Nacional de Educación, UNAE. Sus intereses de investigación son: políticas lingüísticas e innovación curricular.

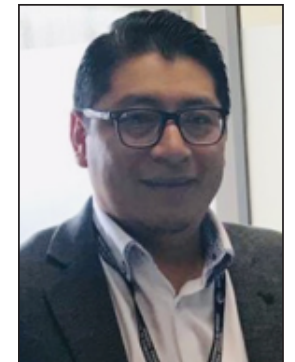

SANTIAGO SANGUÑA

- Profesor de Idiomas extranjeros y español ELE. Sus estudios de tercer cuarto nivel los realizó en la Universidad Central del Ecuador, Universidad Tecnológica Indoamérica, y Universidad Regional Autónoma de los Andes. Actualmente cursa estudios de doctorado en Lengua, Literatura Cultura y sus Aplicaciones en la Universida Politécnica de Valencia- España. Se ha desempeñado como profesor de inglés alrededor de 15 años en prestigiosas universidades del Ecuador.

- Desde el año 2012 es profesor titular del Instituto Académico de Idiomas de la Universidad Central del Ecuador. A partir de junio 2018 cumple funciones de Director de instituto antes mencionado. 